\title{
Pattern and Extent of Utilization of Social Welfare Schemes by the Elderly in Northern India: An Observational Study
}

\author{
Jasjeet Kaur Sidhu ${ }^{1}$, Kirtan Rana ${ }^{1}$, Poonam Khanna ${ }^{1} \&$ Tarundeep Singh ${ }^{1}$ \\ ${ }^{1}$ Postgraduate Institute of Medical Education and Research, Chandigarh, India \\ Correspondence: Dr. Tarundeep Singh, Associate Professor, Department of Community Medicine and School of \\ Public Health, Postgraduate Institute of Medical Education and Research, Chandigarh 160012, India.
}

Received: August 16, 2020

doi:10.20849/ajsss.v5i3.789
Accepted: September 14, 2020

Online Published: October 10, 2020

URL: https://doi.org/10.20849/ajsss.v5i3.789

\begin{abstract}
Background: With the increase in the elderly population in India, state and central government have initiated many schemes for the welfare of the elderly. The current study ascertained the pattern and extent of utilization of social welfare services by the elderly in the rural area of Punjab, a north Indian state.

Results: Out of 400 participants, most (72\%) of the respondents were females. About $99.5 \%$ had an awareness about and $91 \%$ were utilizing at least one social welfare scheme. A statistically significant difference was found between the utilization of schemes for availing healthcare services and medicines $(p=0.001)$ and fulfilling basic needs ( $p=0.01$ ) among rural and urban participants. A significant difference was seen in the number of schemes utilized with economic dependence, source of income, and social class $(\mathrm{p}<0.05)$. Lack of knowledge for a scheme was the most common reason for the non-utilization of schemes.

Conclusion: The study concluded that the utilization of social welfare schemes can be increased by making them elderly-friendly.
\end{abstract}

Keywords: awareness, elderly population, social welfare schemes, utilization, elderly-friendly

\section{Introduction}

As India moves closer to becoming the most populous country in the world, it is facing a serious concern of population aging. This growing proportion of the elderly, combined with declining birth rates and increased longevity, has made population aging as one of the greatest challenges of the 21st century [1]. The overall population of India is expected to grow by 56 percent whereas the 60 plus population will increase to almost 34 crores (326\% increase as of current population) by the year 2050 [1]. As per 2018 report, the 60 plus population in India was $8.1 \%$ of the total population [2]. Estimates say that nearly $45 \%$ of India's disease burden by 2030 will be borne by the elderly. Therefore, there is a need for better economic and social security arrangements for the elderly so that we add "life to years" and not just "years to life" [3].

The Government of India drafted the National Policy on Older Persons (NPOP) in 1999, way ahead of the Madrid International Plan of Action on Ageing (MIPAA), when less than 7\% of the population was aged 60 and above [4]. Being a signatory to the MIPAA, India is committed to ensuring that people can age and live with dignity from a human- rights perspective. Hence, a number of measures have been taken by the Indian government to provide some sense of social security to the elderly such as Indira Gandhi National Old Age Pension Scheme (IGNOAPS), Rashtriya Swasthya Bima Yojana, Annapurna scheme, Maintenance and Welfare of Parents and Senior Citizen Act 2007, National Program for Health Care of the Elderly (NPHCE), Integrated Programme for Older Persons (IPOP) etc [5,6].(India, 2016; Ministry of Rural Development, 2000; Ministry of Social Justice \& Empowerment, 2016) Beside this there are other central facilities/services designed specifically for the elderly such as police are asked to pay special attention to the protection of life and property of the senior citizens, tax concessions, priority must be given to the complaints of senior citizens, investment schemes with higher rate of interest for elderly, travel facilities (concession in air fares, rail fares and reservation of seats in state transport buses), old age solution portal, health and life insurance schemes till 65 years of age among others[7].

The state of Punjab has also implemented measures for elderly such as old-age pension scheme of Punjab government, Bhagat Puran Singh Scheme, Atta Dal scheme, Provision of Identity Cards for Senior Citizens, Punjab Maintenance and welfare of Parents and Senior Citizens Act, 2007, Residential and Day Care Services for 
the Elderly, Concessional Bus Travel Facility for Women[8,9,10,11,12]. These social security measures are important and at times the only means of support for elderly. However, to assess the impact and steps for further improvement in the future of such measures, it is important to have information about the level of awareness and practical problems faced by the elderly while utilizing them.

A report by the UN Population Fund 2012 has predicted that India's current hospital and welfare services are insufficient for the strain they will face as the pace of population aging increases. The report further pointed out that only about $18 \%$ of all the elderly in India are accessing old-age pensions and only a quarter of widowed elderly women are benefitting from the widow pension scheme[13] Various studies have been done in different states of India to know about the state-specific schemes for the elderly's, regarding awareness, utilization, barriers faced utilizing these schemes[14,15,16,17,18,19,20]

From the above, it becomes important that each state carry out studies to understand the utilization pattern of their welfare schemes for the elderly, find out the shortcomings and tweak the schemes to better serve the elderly in a wholesome way.

The current study attempts to find out the utilization patterns of social welfare schemes by the elderly and the obstacles faced by the elderly in the process in the north Indian state of Punjab.

\section{Methodology}

\subsection{Study Settings}

The study was conducted between May-July 2019 in Fatehgarh Sahib district of Punjab having a population of 600,163 as per census 2011 [21]. Since before this, no study was found to have been conducted on this topic in this area default prevalence (p) of knowledge regarding welfare schemes among elderly of 50\% with an absolute precision of $5 \%$ was assumed. Using the formula, $n=4 \mathrm{pq} / \mathrm{d}^{2}$; sample taking $10 \%$ non-response rate final sample was fixed at 400.Considering, $8 \%$ of the elderly (as per census India 2011) and 5,000 population of one sub-center, $8 / 100 \times 5000=400$ (each SC would have 400 elderly). Since Fatehgarh Sahib is largely rural, $75 \%$ (300) of the sample was taken from the rural area. The study subjects in each area (rural; Khera, Nandpur Kalor, Sanghol, and urban; Bassi Pathana) were selected by a simple random technique using the lists available with ANM. The information about the eligible subjects was also taken from the Public Health Nurses (PHNs) of the urban health center attached to the medical institution and the Anganwadi workers and ASHAs of the respective areas. If some elderly did not consent for the interview, the next name was selected from the list. The elderly people who were seriously ill, bedridden, audio-visually impaired, and mentally unstable were excluded from participation.

\subsection{Patient and Public Involvement Statement}

Members of the public (senior faculty members/experts) were involved in setting the research question and developing the study, through face-to-face meetings and revisions of the protocol. Participants were not a involved in the design and conduct of study, choice of outcomes, recruitment, or dissemination.

\subsection{Survey Administration}

Data was collected after explaining the objectives of the study and taking informed consent, using semi-structured interview schedule consisting of closed and open-ended questions. Variables in the questionnaire comprised about the knowledge of the existence of the recent social security schemes, utilization of these schemes, and about quality of life. The questionnaire was pretested and relevant changes were done based on responses.

The interview was thematically grouped into three areas:1) Questions about Social Demographic data. 2) Questions about their quality of life. 3) Questions about the knowledge of welfare schemes.

WHOQOL-BREF scale was used to measure the quality of life. This instrument contains four domains namely physical health, psychological, social relationships, and the environment with a total of 26 questions[22].(World Health Organization, 2012) As per the WHO guidelines, 25 raw scores for each domain were calculated by adding values of single items and it was then transformed to a score ranging from 0 to 100 , where 100 is the highest and 0 is the lowest value. The mean score, minimum, maximum, and standard deviation were calculated. The cut off limit for domain score was set at 60 . The score of equal to or more than 60 was a good quality of life and below 60 was the poor quality of life. This questionnaire was translated to Punjabi and then, back to English to assess the liability of the instrument. Pilot-test was done before the survey.

\subsection{Statistical Analysis}

Data was entered into Microsoft Office Excel 2007, coded and analyzed using SPSS v 16. Chi square test was used to find the association between the outcome and covariates. P-value $<0.05$ was considered significant. 


\section{Results}

Out of 400 participants enrolled in the study, $288(72 \%)$ were females, around $234(58.5 \%)$ were in the age group 60-69 years followed by $108(27 \%)$ and 58(14.5\%) in 70-79 years and 80+ years age group respectively. The majority of the participants, $245(61.3 \%)$ had never been educated in school. Out of total, $333(83.3 \%)$ of the study participants were living in a joint family and $76.3 \%$ of the study participants had either retired or stopped working. About 31\% (123) participants belonged to lower middle class followed by 119 (29.8\%) participants belonging to upper class (Table 1). Majority of the participants, $276(69 \%)$ were partially economically dependent on others. About 286 (71.5\%) participants mentioned welfare pension as their source of their income.

Table 1. Sociodemographic characteristics of the study participants $(\mathrm{N}=400)$

\begin{tabular}{|c|c|}
\hline Demographic variables & $\mathbf{N}(\%)$ \\
\hline \multicolumn{2}{|l|}{ Gender } \\
\hline Male & $112(28)$ \\
\hline Female & $288(72)$ \\
\hline \multicolumn{2}{|l|}{ PLACE OF RESIDENCE } \\
\hline Rural & $300(75)$ \\
\hline Urban & $100(25)$ \\
\hline \multicolumn{2}{|l|}{ AGE (yrs) } \\
\hline $60-69$ & $234(58.5)$ \\
\hline $70-79$ & $108(27)$ \\
\hline $80+$ & $58(14.5)$ \\
\hline \multicolumn{2}{|l|}{ SCHOOLING } \\
\hline $1-4 \mathrm{yrs}$ & $13(3.3)$ \\
\hline $5-7 \mathrm{yrs}$ & $81(20.3)$ \\
\hline $8+\mathrm{yrs}$ & $61(15.3)$ \\
\hline Nil & $245(61.3)$ \\
\hline \multicolumn{2}{|l|}{ LIVING ARRANGEMENT } \\
\hline Alone & $29(7.2)$ \\
\hline With life-partner & $33(8.3)$ \\
\hline In a joint family & $333(83.2)$ \\
\hline Others & $5(1.3)$ \\
\hline \multicolumn{2}{|l|}{ EMPLOYMENT STATUS } \\
\hline Never worked & $163(35.8)$ \\
\hline Currently working & $95(23.8)$ \\
\hline Stopped working or retired & $162(40.5)$ \\
\hline \multicolumn{2}{|l|}{ ECONOMIC DEPENDENCE } \\
\hline Fully dependent & $50(12.5)$ \\
\hline Partially dependent & $276(69)$ \\
\hline $\begin{array}{ll}\text { Fully independent } \\
\end{array}$ & $74(18.5)$ \\
\hline \multicolumn{2}{|l|}{ SOURCE OF INCOME } \\
\hline Retired pension & $22(5.5)$ \\
\hline Welfare pension & $286(71.5)$ \\
\hline
\end{tabular}




\begin{tabular}{|c|c|}
\hline From children & $37(9.25)$ \\
\hline Self-employment & $31(7.75)$ \\
\hline Pension + Employment & $24(6)$ \\
\hline \multicolumn{2}{|l|}{ SOCIAL CLASS } \\
\hline Upper Class & $119(29.8)$ \\
\hline Upper Middle class & $18(4.5)$ \\
\hline Lower middle Class & $123(30.8)$ \\
\hline Upper lower Class & $34(8.5)$ \\
\hline Lower Class & $106(26.5)$ \\
\hline
\end{tabular}

Awareness about the state-level schemes was much higher at around 99.5\% (taking in account the schemes with the maximum awareness) as compared to the national level schemes being just $46.6 \%$. There was a statistically significant difference in awareness about IGNOAPS, Annapurna scheme, IGNWPS, and ticket concession among rural and urban study participants for center sponsored schemes. There was no statistically significant difference seen regarding awareness of state-specific scheme between the rural and urban study participants (Table 2).

Table 2. Awareness regarding various schemes for the elderly among study participants

\begin{tabular}{cccc}
\hline \multicolumn{1}{l}{$\begin{array}{l}\text { Various schemes and provisions } \\
\text { Central schemes }\end{array}$} & Rural (n=300) & Urban (n=100) & p-value \\
\hline IGNOAPS & & & \\
\hline Annapurna scheme & $14(4.7)$ & $42(42)$ & 0.000 \\
\hline IGNWPS & 0 & $2(2)$ & 0.014 \\
\hline Rashtriya Swasthya Bima Yojana & $12(4.0)$ & $42(42)$ & 0.000 \\
\hline Train ticket concession & $14(4.7)$ & $4(4)$ & 0.781 \\
\hline Preference for a telephone connection & $126(42)$ & $58(58)$ & 0.005 \\
\hline Higher interest for deposits in bank/post offices & $17(5.7)$ & $1(1)$ & 0.051 \\
\hline Income tax benefits & $39(13)$ & $13(13)$ & 1 \\
\hline Punjab state-specific schemes & $11(3.7)$ & $1(1)$ & 0.176 \\
\hline Senior citizen card & & & 0.578 \\
\hline Bidow/Old age pension scheme & $23(7.7)$ & $6(6)$ & 0.795 \\
\hline Atta dal scheme & $296(98.7)$ & $99(99)$ & 0.487 \\
\hline Bus/train seat reservation & $252(84)$ & $81(81)$ & 2 \\
\hline
\end{tabular}

A statistically significant difference was seen for the utilization of social welfare schemes (Widow/Old age pension scheme, Atta dal scheme) for fulfillment of basic needs $(\mathrm{p}=0.01)$ and (Bhagat Puran Singh Bima Yojna) for healthcare and medicines $(0.001)$ between rural and urban study participants. A statistically significant difference was also seen among the study participants regarding the sufficiency of funds under various social welfare schemes (Table 3). About 332 study participants had been helped by neighbors and ASHA in availing the various social welfare schemes. 
Table 3. Utilization of various social welfare schemes and responses on the sufficiency of funds under social welfare schemes by the study participants

\begin{tabular}{|c|c|c|c|c|}
\hline \multirow[b]{2}{*}{ Purpose of utilization } & \multicolumn{4}{|c|}{ Place of residence } \\
\hline & $\begin{array}{l}\text { Rural } \\
(\mathrm{n}=300)\end{array}$ & $\begin{array}{l}\text { Urban } \\
(\mathrm{n}=100)\end{array}$ & Total $(n=400)$ & p-value \\
\hline Basic needs & $96(38.1)$ & $52(53.1)$ & $148(42.3)$ & 0.011 \\
\hline Healthcare and medicine & $179(71)$ & $86(87.8)$ & $265(75.7)$ & 0.001 \\
\hline Give to children/spouse & $10(4)$ & $5(5.1)$ & $15(4.3)$ & 0.638 \\
\hline Loan payments & $4(1.6)$ & 0 & $4(1.1)$ & 0.21 \\
\hline Own needs & $80(31.7)$ & $33(33.7)$ & $113(32.3)$ & 0.729 \\
\hline Others* & $3(1.2)$ & 0 & $3(0.9)$ & 0.278 \\
\hline \multicolumn{5}{|l|}{ People helped in availing scheme } \\
\hline Children & $10(4)$ & $1(1)$ & $11(3.2)$ & \multirow{3}{*}{0.232} \\
\hline Relatives & $2(0.8)$ & 0 & $2(0.6)$ & \\
\hline Neighbors and ASHAs & $235(95.1)$ & $97(99)$ & $332(96.2)$ & \\
\hline \multicolumn{5}{|l|}{ Sufficiency of the funds } \\
\hline Enough to meet basic needs & $28(11.2)$ & $4(4)$ & $32(9.2)$ & \multirow{3}{*}{0.001} \\
\hline $\begin{array}{l}\text { Sometimes found difficult to meet basic } \\
\text { needs }\end{array}$ & $38(15.3)$ & $33(33)$ & $71(20.5)$ & \\
\hline Not sufficient to meet basic needs & $181(74.8)$ & $61(62)$ & $242(70.1)$ & \\
\hline
\end{tabular}

* basic needs constitute being able to getting 2 decent meals a day while own needs mean being able to do things like getting sweets, buying new clothes or giving presents to grandchildren.

Lack of knowledge regarding the schemes was found to be the most common reason as a barrier to access that social welfare scheme, rejection of forms multiple times, not knowing which facility can be availed by using a particular scheme, and schemes not well implemented or advertised by the concerned authorities were major reasons for non-utilization of schemes.

There was a significant difference in the number of schemes utilized with a place of residence, economic dependence, source of income, and social class $(\mathrm{p}<0.05)$ as shown in Table 4 . Around $91 \%$ of the study subjects utilized at least 1 scheme while $100 \%$ of subjects knew about 1 scheme. Awareness of at least 2,3 and 4 schemes was $99.3 \%, 90 \%$, and $59.8 \%$ while utilization of at least 2,3 and 4 schemes was $79.01 \%, 58 \%$, and $25.30 \%$ respectively. 
Table 4. Association between various utilization levels and demographic characteristics of the study population

\begin{tabular}{|c|c|c|c|c|}
\hline Demographic variables & $\begin{array}{c}\text { Utilization } \\
\text { level } 1\end{array}$ & $\begin{array}{c}\text { Utilization } \\
\text { level } 2\end{array}$ & $\begin{array}{c}\text { Utilization } \\
\text { level } 3\end{array}$ & $\begin{array}{c}\text { Utilization } \\
\text { level } 4\end{array}$ \\
\hline \multicolumn{5}{|l|}{ GENDER } \\
\hline Female & $265(92 \%)$ & $224(74.7 \%)$ & $164(54.7 \%)$ & $62(20.7 \%)$ \\
\hline Male & $98(87.5 \%)$ & $86(76.8 \%)$ & $70(62.5 \%)$ & $36(32.1 \%)$ \\
\hline p-value & 0.162 & 0.498 & 0.255 & 0.048 \\
\hline \multicolumn{5}{|c|}{ PLACE OF RESIDENCE } \\
\hline Rural & $264(88 \%)$ & $224(74.7 \%)$ & $164(54.7 \%)$ & $62(20.7 \%)$ \\
\hline Urban & $99(99 \%)$ & $92(92 \%)$ & $68(68 \%)$ & $39(39 \%)$ \\
\hline p-value & 0.001 & 0.000 & 0.019 & 0.000 \\
\hline \multicolumn{5}{|l|}{ AGE } \\
\hline $60-69$ & $211(90.2 \%)$ & $185(79.1 \%)$ & $137(58.5 \%)$ & $61(26.1 \%)$ \\
\hline $70-79$ & $97(89.8 \%)$ & $86(79.6 \%)$ & $64(59.3 \%)$ & $30(27.8 \%)$ \\
\hline $80+$ & $55(94.8 \%)$ & $45(77.6 \%)$ & $31(53.4 \%)$ & $10(17.2 \%)$ \\
\hline p-value & 0.58 & 0.953 & 0.744 & 0.298 \\
\hline \multicolumn{5}{|l|}{ SCHOOLING } \\
\hline $1-4 \mathrm{yrs}$ & $11(84.6 \%)$ & $9(69.2 \%)$ & $7(53.8 \%)$ & $5(38.5 \%)$ \\
\hline $5-7 y r s$ & $70(86.4 \%)$ & $65(80.2 \%)$ & $51(63 \%)$ & $23(28.4 \%)$ \\
\hline $8+y r s$ & $53(96.9 \%)$ & $45(73.8 \%)$ & $37(60.7 \%)$ & $22(36.1 \%)$ \\
\hline Nil & $229(93.5 \%)$ & $197(80.4 \%)$ & $137(55.9 \%)$ & $51(20.8 \%)$ \\
\hline p-value & 0.131 & 0.547 & 0.677 & 0.047 \\
\hline \multicolumn{5}{|l|}{ LIVING ARRANGEMENT } \\
\hline Alone & $28(96.6 \%)$ & $24(82.8 \%)$ & $16(55.2 \%)$ & $9(31 \%)$ \\
\hline With life-partner & $32(97 \%)$ & $31(93.9 \%)$ & $23(69.7 \%)$ & $11(33.3 \%)$ \\
\hline In joint family & $298(89.4 \%)$ & $256(76.8 \%)$ & $190(57.05 \%)$ & $80(24.02 \%)$ \\
\hline Others & $5(100 \%)$ & $5(100 \%)$ & $3(60 \%)$ & $1(20 \%)$ \\
\hline p-value & 0.206 & 0.089 & 0.599 & 0.734 \\
\hline \multicolumn{5}{|c|}{ EMPLOYMENT STATUS } \\
\hline Never worked & $125(87.4 \%)$ & $103(72 \%)$ & $68(47.6 \%)$ & $24(16.8 \%)$ \\
\hline Currently working & $88(92.6 \%)$ & $78(82.1 \%)$ & $56(58.9 \%)$ & $28(29.5 \%)$ \\
\hline Stopped working or retired & $150(92.5 \%)$ & $135(83.3 \%)$ & $108(66.6 \%)$ & $49(30.2 \%)$ \\
\hline p-value & 0.533 & 0.131 & 0.007 & 0.041 \\
\hline \multicolumn{5}{|c|}{ ECONOMIC DEPENDENCE } \\
\hline Fully dependent & $31(62 \%)$ & $21(42 \%)$ & $8(16 \%)$ & $4(8 \%)$ \\
\hline Partially dependent & $270(97.8 \%)$ & $243(88 \%)$ & $190(68.8 \%)$ & $78(28.3 \%)$ \\
\hline Fully independent & $62(83.8 \%)$ & $52(70.3 \%)$ & $34(45.9 \%)$ & $19(25.7 \%)$ \\
\hline p-value & 0.000 & 0.000 & 0.000 & 0.01 \\
\hline \multicolumn{5}{|c|}{ SOURCE OF INCOME } \\
\hline Retired pension & $17(77.3 \%)$ & $12(54.5 \%)$ & $7(31.8 \%)$ & $6(27.3 \%)$ \\
\hline Welfare pension & $286(100 \%)$ & $258(90.2 \%)$ & $202(70.6 \%)$ & $83(29 \%)$ \\
\hline
\end{tabular}




\begin{tabular}{lcccc}
\hline From children & $21(56.8 \%)$ & $13(35.1 \%)$ & $1(2.7 \%)$ & 0 \\
\hline Self-employment & $19(61.3 \%)$ & $13(41.9 \%)$ & $5(16.1 \%)$ & $2(6.5 \%)$ \\
\hline Pension + Employment & $20(83.3 \%)$ & $20(83.3 \%)$ & $17(70.8 \%)$ & $10(41.7 \%)$ \\
\hline p-value & $\mathbf{0 . 0 0 0}$ & $\mathbf{0 . 0 0 0}$ & $\mathbf{0 . 0 0 0}$ & $\mathbf{0 . 0 0 0}$ \\
\hline \multicolumn{1}{c}{ SOCIAL CLASS } & & & \\
\hline Upper Class & $92(77.3 \%)$ & $71(59.7 \%)$ & $43(36.1 \%)$ & $24(20.2 \%)$ \\
\hline Upper Middle class & $14(77.8 \%)$ & $13(72.2 \%)$ & $10(55.6 \%)$ & $3(16.7 \%)$ \\
\hline Lower middle Class & $122(99.2 \%)$ & $109(88.6 \%)$ & $79(64.2 \%)$ & $36(29.3 \%)$ \\
\hline Upper lower Class & $32(94.1 \%)$ & $30(88.2 \%)$ & $25(73.5 \%)$ & $13(38.2 \%)$ \\
\hline Lower Class & $103(97.2 \%)$ & $93(87.7 \%)$ & $75(70.8 \%)$ & $25(23.6 \%)$ \\
\hline p-value & $\mathbf{0 . 0 0 0}$ & $\mathbf{0 . 0 0 0}$ & $\mathbf{0 . 0 0 0}$ & $\mathbf{0 . 1 6}$ \\
\hline TOTAL & $\mathbf{9 1 \%}$ & $\mathbf{7 9 . 0 1 \%}$ & $\mathbf{5 8 \%}$ & $\mathbf{2 5 . 3 0 \%}$ \\
\hline
\end{tabular}

Out of the 360 subjects who knew about at least 3 schemes, only 228 (63.30\%) were using all the three schemes they knew about.

When WHOQOL Bref domains were studied with the awareness of schemes, only the environmental domain $(\mathrm{p}=0.006)$ has shown a significant difference in the quality of life among people who knew less than or greater than 4 social welfare schemes. When WHOQoL Bref domains were studied with the utilization of social welfare scheme services, there was a significant difference in the quality of life among participants who were utilizing less than 3 social welfare scheme services and those utilizing more than 3 social welfare scheme services. The difference was statistically significant in the physical $(\mathrm{p}=0.001)$ and environmental $(\mathrm{p}=0.03)$ domains (Table 5).

Table 5. WHOQoL Bref domains and awareness \& utilization of social welfare service for elderly

\begin{tabular}{|c|c|c|c|c|c|c|c|c|c|}
\hline \multirow{2}{*}{$\begin{array}{l}\text { WHOQOL Bref } \\
\text { Domains }\end{array}$} & & \multicolumn{4}{|c|}{ Awareness } & \multicolumn{4}{|c|}{ Utilization } \\
\hline & & $\begin{array}{l}\text { Greater } \\
\text { than } 4 \\
\text { knowns }\end{array}$ & $\begin{array}{l}\text { Less } \\
\text { than } 4 \\
\text { knowns }\end{array}$ & Total & P-value & $\begin{array}{l}\text { Greater } \\
\text { than } 3 \\
\text { utilized }\end{array}$ & $\begin{array}{l}\text { Less } \\
\text { than } 3 \\
\text { utilized }\end{array}$ & Total & P-value \\
\hline \multirow{2}{*}{$\begin{array}{l}\text { Domain } \\
\text { Environmental }\end{array}$} & $\begin{array}{l}\text { Good } \\
\text { QoL }\end{array}$ & $\begin{array}{l}44 \\
(35.2)\end{array}$ & $\begin{array}{l}32 \\
(19.0)\end{array}$ & $\begin{array}{l}101 \\
(25.3)\end{array}$ & \multirow[t]{2}{*}{0.01} & $\begin{array}{l}28 \\
(30.1)\end{array}$ & $\begin{array}{l}55 \\
(31.1)\end{array}$ & $\begin{array}{l}101 \\
(25.3)\end{array}$ & \multirow[t]{2}{*}{0.01} \\
\hline & $\begin{array}{l}\text { Poor } \\
\text { QoL }\end{array}$ & $\begin{array}{l}81 \\
(64.8)\end{array}$ & $\begin{array}{l}136 \\
(81.0)\end{array}$ & $\begin{array}{l}299 \\
(74.8)\end{array}$ & & $\begin{array}{l}65 \\
(69.9)\end{array}$ & $\begin{array}{l}122 \\
(68.9)\end{array}$ & $\begin{array}{l}299 \\
(74.8)\end{array}$ & \\
\hline \multirow[t]{2}{*}{$\begin{array}{l}\text { Domain } \\
\text { Psychological }\end{array}$} & $\begin{array}{l}\text { Good } \\
\text { QoL }\end{array}$ & $\begin{array}{l}16 \\
(12.8)\end{array}$ & $\begin{array}{l}20 \\
(11.9)\end{array}$ & $\begin{array}{l}50 \\
(12.5)\end{array}$ & \multirow[t]{2}{*}{0.95} & $\begin{array}{l}16 \\
(17.2)\end{array}$ & $\begin{array}{l}24 \\
(13.6)\end{array}$ & $\begin{array}{l}50 \\
(12.5)\end{array}$ & \multirow[t]{2}{*}{0.09} \\
\hline & $\begin{array}{l}\text { Poor } \\
\text { QoL }\end{array}$ & $\begin{array}{l}109 \\
(87.2)\end{array}$ & $\begin{array}{l}148 \\
(88.1)\end{array}$ & $\begin{array}{l}350 \\
(87.5)\end{array}$ & & $\begin{array}{l}77 \\
(82.8)\end{array}$ & $\begin{array}{l}153 \\
(86.4)\end{array}$ & $\begin{array}{l}350 \\
(87.5)\end{array}$ & \\
\hline \multirow[t]{2}{*}{$\begin{array}{l}\text { Domain } \\
\text { Physical }\end{array}$} & $\begin{array}{l}\text { Good } \\
\text { QoL }\end{array}$ & $\begin{array}{l}47 \\
(37.6)\end{array}$ & $\begin{array}{l}65 \\
(38.7)\end{array}$ & $\begin{array}{l}152 \\
(38.0)\end{array}$ & \multirow[t]{2}{*}{0.97} & $\begin{array}{l}45 \\
(48.4)\end{array}$ & $\begin{array}{l}57 \\
(32.2)\end{array}$ & $\begin{array}{l}152 \\
(38.0)\end{array}$ & \multirow[t]{2}{*}{0.03} \\
\hline & $\begin{array}{l}\text { Poor } \\
\text { QoL }\end{array}$ & $\begin{array}{l}78 \\
(62.4)\end{array}$ & $\begin{array}{l}103 \\
(61.3)\end{array}$ & $\begin{array}{l}248 \\
(62.0)\end{array}$ & & $\begin{array}{l}48 \\
(51.6)\end{array}$ & $\begin{array}{l}120 \\
(67.8)\end{array}$ & $\begin{array}{l}248 \\
(62.2)\end{array}$ & \\
\hline
\end{tabular}

\section{Discussion}

The current study was done to find out the pattern and extent of utilization of social welfare schemes of the elderly in rural Punjab and how that pattern was affected by socio-demographic factors. It was a cross-sectional study covering three rural and one semi-urban areas in the district of Fatehgarh Sahib, Punjab, North India.

Our study found that majority of the study participants were females $288(72 \%)$ and nearly $58.5 \%$ of participants were in the age group of 60-69. A study by Nevidata et al also found that majority of study participants in their 
study were of age group 60-69 years[18]. Kohli et al found their study population having maximum people of age group 60-74 years and the majority of the study participants to be females (54.2\%) [17]. Dhanasekaran $\mathrm{G}$ et al also reported a similar profile of study participants. A large part of the study participants 245(61.3\%) was illiterate. Higher illiteracy was reported by Nivedita et al $(81.9 \%)$ and Elango et al $(78 \%)$ in Tamil Naidu [15,18]. The high illiteracy in our study is attributed to the fact that the study sample size had mostly females and during the decades of 1940s-1950s, when the female literacy level in the country was 7.3\%-7.9\% and educating the girls was not the norm in the country [23].

Our study found that the awareness of social welfare schemes was around $99.4 \%$ for at least one of the state social service schemes while that for the national social service scheme was $46.4 \%$. Goswami et al. found around $86.9 \%$ of awareness regarding at least one social service scheme among study participants [16]. Since most of the schemes available at the national level are also available at the state level, people tend to remember the state level scheme more than the central level scheme. Vidhate et al found that the awareness of social welfare schemes increases with an increase as the participant's age increases in their study population [20]. Our study didn't conclude any similar correlation between age and increase awareness. Kohli et al also concluded no association of age, family type, caste with the awareness level of social welfare schemes which is similar to our study [17]. Our study found that maximum awareness was for the state-level social welfare schemes such as Atta dal scheme (99.5\%) followed by widow/ old-age pension scheme (98.8\%) and Bhagat Puran Singh scheme (83.3\%). The reason for more awareness among people for the state-level social welfare schemes can be related to the knowledge of the source person i.e ASHA. Awareness about provisions like train ticket concession, higher interest rate, income tax benefits, and preference for telephone connection was low because these were not being used by the elderly frequently. Similar findings were reported from the study conducted by Janki et al, in the Nainital district of Uttarakhand [14].

In our study found that $91 \%$ of the participants were utilizing at least one of the social welfare schemes. The study further found that with an increase in the number of services being utilized, the percentage of users declines sharply. The utilization of at least one social welfare scheme was around $42.2 \%$ among study participants in Delhi [15] which is very less than that of the participants in our study group (91\%). Our study found that the quality of life remained poor when WHOQoL BREF domains were correlated with the utilization of the social welfare services among the study participants. This shows that the schemes haven't been effective in bringing any improvement in the quality of life of the elderly. Respect and love from the children and grandchildren and financially stable household decided whether the elderly were happy and satisfied with their life. Schemes didn't play much role in providing such satisfaction to the elderly in absence of loving and financially sound children. Our study found that $75.7 \%$ of the study participants utilized the social welfare schemes for healthcare and medicines followed by basic needs $(42.3 \%)$.

Among those who didn't utilize the social welfare schemes, lack of knowledge related to the scheme was the main reason, followed by the non-requirement of the scheme. Nivedita et al found that lack of awareness about the major challenge faced during the utilization of schemes. Kohli et al 2017, found corruption and the tedious administrative procedures to be the major barriers for non-utilization of service. The barriers in accessing the service can vary from place to place ranging from the need of service to availability of service. A study by Hemalatha $\mathrm{et} \mathrm{al}$, in the rural area of Bangalore concluded activities of daily living, need for medicines and medical aids, energy, and fatigue, mobility, pain, and discomfort, sleep and rest and work capacity act as the barrier factors in the utilization of the social welfare scheme [19].

The elderly population in India is growing at a rate of 3.5 percent, double the rate of the population as a whole [14]. As a result, the famous 'dividend' will age and by the middle of the century, India's elderly population will dramatically increase. With this kind of aging situation, all aspects of care for the elderly be it financial, health, or shelter, need serious overhauling. This situation becomes even more acute among the poor elderly, who can't work due to aging and associated deteriorating health, and also, don't have any savings to fall back on. To prepare the country to handle this situation, studying the current working of social welfare schemes and problems plaguing them, is of utmost importance. Also, efforts need to be made to prepare healthcare providers who can provide care to the elderly as significant manpower shall be involved in such activities $[24,25,26]$. Since elderly are also likely to suffer from non-communicable diseases and multiple illnesses, which entail much higher costs to the healthcare and social systems, the health systems also need to be prepared for this change in the nature of ailments afflicting the population $[27,28,29]$. Also, financial support to the elderly may contribute to reducing loneliness for people who have significant healthcare needs [30]. The study included rural and semi-urban area and both central and state-level schemes were assessed. Most studies conducted earlier included either the urban area or rural areas and have not included both central and state-level schemes together. Further, the study results can be generalized in 
view of adequate sample size for all the parameters. It included quantitative as well as qualitative aspects where quality of life and its association with awareness and utilizations of schemes were also examined. The ratio of females and males was more than double representing skewed gender ratio. In-depth interviews could have been taken to get better understanding about the reasons for barriers. The social class could not be perfectly addressed as many elderlies lived in joint families.

\section{Conclusion}

Awareness about the state levels schemes was much higher $99.5 \%$ as compared to the national level schemes being just $46.6 \%$. The utilization of at least one social welfare service was $91 \%$ among the study participants. The socio-demographic characteristics didn't show an association with awareness levels. It was only at awareness level 4 and 5 were education levels showed significant difference. The utilization was lower than awareness for all the schemes and provisions. This was because the information that the elderly had was often incomplete. They didn't know whether they qualified for the schemes or provisions. If they knew they qualified, then they didn't know where to go to get them enrolled. If enrollment was done, they didn't know what they were entitled to through the schemes, this all hampered the utilization of the schemes. The whole process of providing welfare schemes for the elderly is to ensure good quality life for the elderly. But, unfortunately, the whole process of benefiting from these schemes is not designed to be elderly-friendly. There is a need to not just focus on providing for the needs of the elderly, we also need to focus on designing the path to acquiring those benefits as easy as possible.

\section{Recommendations}

The following recommendations can be made according to the present study:

- Campaigns to inform and empower the elderly to access the welfare schemes need to be planned in a way so that penetration to the most underserved is achieved.

- Since ASHAs are the main source of information for the elderly, they should be fully equipped with information about the schemes and also on how to utilize those schemes to the fullest.

- To enhance the utilization of the benefits of the scheme being given under them like pension money or food grains should always be given on time without any delays.

- The elderly should not only be enrolled in a scheme but should be properly guided as to how and what all benefits they get from that particular scheme.

- More studies need to be conducted to understand the barriers on the administrative side and political impact on the working of the schemes.

\section{Ethics and Dissemination}

Ethical clearance was obtained from the Institutional Ethics Committee, PGIMER, and Chandigarh. We aim to present our findings at scientific conferences and in peer-reviewed journals.

\section{Acknowledgments}

JKS and TS were involved in the conception, design, data collection and analyses and interpretation; wrote the draft of the paper. TS, KR, PK were involved in reviewing the study and drafts of the manuscript; and read and approved the final manuscript and agreed for submission.

\section{References}

[1] India Ageing Population: Demographic time bomb: Young India ageing much faster than expected. (n.d.). ET Online; [ 2018 Aug 18]. Retrieved 12 July 2020, from https://economictimes.indiatimes.com/news/politics-and-nation/demographic-time-bomb-young-india-agein g-much-faster-than-expected/articleshow/65382889.cms

[2] Sample Registration System Statistical Report 2018. (2018). New Delhi: Office of the Registrar General \& Census Comissioner, India Ministry of Home Affairs Government of India, p. 335. https://doi.org/10.4324/9780203791462-3

[3] World Health Day 2012: "Add life to years, not years to life" says WHO India | TheHealthSite.com. (n.d.). [2020 Jul 12]. Retrieved from https://www.thehealthsite.com/diseases-conditions/world-health-day-2012-add-life-to-years-not-years-to-lif e-says-who-india-8466/ 
[4] Alam, M., Mazumdar, S., \& Yadav, P. (2015). Inequalities in Elderly Health and Wellbeing in India: An Exploration”. United Nations Population Fund (UNFPA), New Delhi, p. 28. BKPAI Working Paper Series II No.5.

[5] Guidelines for Annapurna Scheme. Ministry of Rural Development, G. of I. 2000. 11 p.

[6] Integrated programme for older person, A Central Sector Scheme to improve the quality of life of the Older Persons. Ministry of Social Justice \& Empowerment, 2016, p. 36.

[7] Concessions and Facilities given to Senior Citizens. (n.d.). Retrieved July 12, 2020, from https://vikaspedia.in/social-welfare/senior-citizens-welfare/concessions-and-facilities-given-to-senior-citize ns

[8] Bhagat Puran Singh Sehat Bima Yojana. (n.d.). Retrieved July 12, 2020, from https://mdindiaonline.com/BPSSBY/BPSSBYHomepage.aspx

[9] New Atta Dal scheme from December 1; wheat at Rs 1 per kg. The Economic Times, 2013 Nov. Retrieved from https://economictimes.indiatimes.com/news/politics-and-nation/new-atta-dal-scheme-from-december-1-whe at-at-rs-1-per-kg/articleshow/26590051.cms?from=mdr

[10] Punjab Maintenance and Welfare of Parents and Senior Citizen Rules. 2012.(n.d.). Department of Social Security, Government of Punjab;[2020 Jul 20]. Retrieved from http://www.bareactslive.com/Pun/pu871.htm\#0

[11] Punjab to add 7 lakh more families under "Atta-Dal" scheme. (n.d.). The Economics Times; [2020 Jul 20]. Retrieved from https://economictimes.indiatimes.com/news/economy/policy/punjab-to-add-7-lakh-more-families-under-att a-dal-scheme/articleshow/52332087.cms

[12] Chapter 7 National policies and programmes for elderly. Provisions, R. C. 2013, 3(8).

[13] "Caring for Our Elders : Early Responses" - India Ageing Report 2017. New Delhi, India: UNFPA; p.110. https://doi.org/10.1016/j.arth.2015.06.012

[14] Bartwal, J., Rawat, C. S., \& Awasthi, S. (2016 Sep.). Awareness and Utilization of Geriatric Welfare Services among Elderly in Nainital District of Uttarakhand. National Journal of Community Medicine, 7(9), 727-731.

[15] Elango, S. (1998, Jan.). A Study of Health and Health Related Social Problems in the Geriatric Population in a Rural Area of Tamil Nadu. Indian Journal of Public Health, 42(1), 7-8.

[16] Goswami, A., Ramadass, S., Kalaivani, M., Nongkynrih, B., Kant, S., \& Gupta, S. (2019, Mar.). Awareness and utilization of social welfare schemes by elderly persons residing in an urban resettlement colony of Delhi. Journal of Family Medicine and Primary Care, 8(3), 960-965. https://doi.org/10.4103/jfmpc.jfmpc_28_19

[17] Kohli, C., Gupta, K., Banerjee, B., \& Ingle, G. K. (2017, May). Social Security Measures for Elderly Population in Delhi, India: Awareness, Utilization and Barriers. Journal of Clinical and Diagnostic Research, 11(5), LC10-LC14. https://doi.org/10.7860/jcdr/2017/21271.9814

[18] Nivedita, B. M., Mangala, S., \& Subrahmanyam, G. (2015, Oct.). Utilization of Social Security Schemes among Elderly in Kannamangala , Bengaluru. International Journal of Scientific Study, 3(7), 82-85. https://doi.org/10.17354/ijss/2015/452

[19] Umashankar, H. D. S. D., Hiremath, L. R., \& Sharma, N. (2018, Dec.). Challenges faced in utilization of social security facilities among elderly in a rural area of Bangalore. International Journal of Community Medicine and Public Health, 5(12), 5271. https://doi.org/10.18203/2394-6040.ijcmph20184802

[20] Vidhate, K. B., \& Kundap, R. (2016, Dec.). Awareness about Newly Launched Social Security Schemes among Rural Population in India. National Journal of Community Medicine, 7(12), 12-15. https://doi.org/10.4103/jfmpc.jfmpc_28_19

[21] District census handbook Fatehgarh Sahib. (2014). In Census of India, 2011. Chandigarh: Directorate of Census Operations Punjab, p. 270.

[22] WHOQOL User Manual. (2012). Geneve: World Health Organization. https://doi.org/10.1007/SpringerReference_28001

[23]Provisional population Total Paper 1 of 2011 India. (2011). New Delhi, India: Office of the Registrar General \& Census Comissioner, p. 40. https://doi.org/10.1017/CBO9781107415324.004 
[24] Singh, T., Singh, A., \& Avasthi, A. (2005). Patterns and Quality of long term care for the bedridden patients in Chandigarh. North India. Internet Journal of Geriatrics and Gerontology, 2, 114-9.

[25] Singh, T., Bains, P., \& Singh, A. (2010, March). Status of home based care provision to the bedridden elderly in Chandigarh, North India. Journal of Indian Academy of Geriatrics, 6, 9-13. https://doi.org/10.1371/journal.pone.0176063

[26] Singh, T., Bains, P., \& Singh, A. (2011, Aug.). Profile of home based care givers of bedridden patients in North India. Indian Journal of Community Medicine, 36(2), 114-119.

[27] Singh, T., Rou, P., Lamir, L., et al.. (2016). Assessment of universal healthcare coverage in a district of North India: A rapid cross sectional survey uring tablet computers. PloS One, 11(6), e0157831

[28] Singh, T., Bhatnagar, N., Singh, G. et al.. (2018, April). Healthcare Utilization and expenditure pattersn in the rural areas of Punjab, North India. Journal of Family Medicine and Primary Care, 7(1), 39. https://doi.org/jfmpc.jfmpc_29_17

[29] Verma, M., Grover, S., Tripathy, J. P. et al.. (2019, June). Co-existing Non communicable diseases and mental illnesses amongst the elderly in Punjab, India. European Endocrinology, 15(2), 106. https://doi.org/10.18203/2394-6040.ijcmph20184802

[30] Grover, S., Verma, M., Singh, T., Dahiya, N., \& Nehra, R. (2019, June). Loneliness and its co relates amongst elderly attending non-communicable disease rural clinic attached to a tertiary care centre of North India. Asian Journal of Psychiatry, 4, 189-196.

[31] Senior citizen's Guide Revised Edition 2016. New Delhi, India: Policy Research and Developemnt Department, p. 75. https://doi.org/10.1017/CBO9781107415324.004

\section{Copyrights}

Copyright for this article is retained by the author(s), with first publication rights granted to the journal.

This is an open-access article distributed under the terms and conditions of the Creative Commons Attribution license (http://creativecommons.org/licenses/by/4.0/). 